\title{
Influence of dietary taurine and housing density on oviduct function in laying hens"
}

\author{
Bin DAI ${ }^{\dagger 1}$, Yuan-shu ZHANG ${ }^{1}$, Zi-li MA ${ }^{2}$, Liu-hai ZHENG ${ }^{1}$, Shuang-jie LI $^{1}$, \\ Xin-hong DOU ${ }^{3}$, Jian-sen GONG ${ }^{3}$, Jin-feng MIAO ${ }^{\dagger 1}$ \\ $\left({ }^{1}\right.$ College of Veterinary Medicine, Nanjing Agricultural University, Nanjing 210095, China) \\ ( ${ }^{2}$ Animal Husbandry and Veterinary Bureau of Dongyang, Dongyang 322100, China) \\ ( ${ }^{3}$ Poultry Institute, Chinese Academy of Agricultural Sciences, Yangzhou 225125, China) \\ ${ }^{\dagger}$ E-mail: daibin0205@126.com; miaojinfeng@njau.edu.cn \\ Received Sept. 25, 2014; Revision accepted Apr. 8, 2015; Crosschecked May 13, 2015
}

\begin{abstract}
Experiments were conducted to study the effects of dietary taurine and housing density on oviduct function in laying hens. Green-shell laying hens were randomly assigned to a free range group and two caged groups, one with low-density and the other with high-density housing. Each group was further divided into control (C) and taurine treatment $(T)$ groups. All hens were fed the same basic diet except that the T groups' diet was supplemented with $0.1 \%$ taurine. The experiment lasted $15 \mathrm{~d}$. Survival rates, laying rates, daily feed consumption, and daily weight gain were recorded. Histological changes, inflammatory mediator levels, and oxidation and anti-oxidation levels were determined. The results show that dietary taurine supplementation and reduced housing density significantly attenuated pathophysiological changes in the oviduct. Nuclear factor-KB (NF-KB) DNA binding activity increased significantly in the high-density housing group compared with the two other housing groups and was reduced by taurine supplementation. Tumor necrosis factor- $\alpha$ (TNF- $\alpha$ ) mRNA expression in the high-density and low-density $C$ and T groups increased significantly. In the free range and low-density groups, dietary taurine significantly reduced the expression of TNF- $\alpha$ mRNA. Supplementation with taurine decreased interferon- $\gamma$ (IFN- $\gamma$ ) mRNA expression significantly in the low-density groups. Interleukin 4 (IL-4) mRNA expression was significantly higher in caged hens. IL-10 mRNA expression was higher in the high-density $C$ group than in the free range and low-density $C$ groups. Supplementation with taurine decreased IL-10 mRNA expression significantly in the high-density group and increased superoxide dismutase (SOD) activity in the free range hens. We conclude that taurine has important protective effects against oviduct damage. Reducing housing density also results in less oxidative stress, less inflammatory cell infiltration, and lower levels of inflammatory mediators in the oviduct. Therefore, both dietary taurine and reduced housing density can ameliorate oviduct injury, enhance oviduct health, and promote egg production in laying hens.
\end{abstract}

Key words: Rearing pattern, Taurine, Laying hens, Inflammation, Oviduct injury doi:10.1631/jzus.B1400256

Document code: A

CLC number: S852.23

\section{Introduction}

The oviduct is an amazing organ in hens and other oviparous animals. It provides an environment

\footnotetext{
${ }^{\ddagger}$ Corresponding author

* Project supported by the National Natural Science Foundation of China (Nos. 31101783 and 31472164) and the Special Fund for Independent Innovation of Agricultural Science and Technology in Jiangsu Province of China (No. CX(13)3070)

(D) ORCID: Bin DAI, http://orcid.org/0000-0002-0980-5871

(C) Zhejiang University and Springer-Verlag Berlin Heidelberg 2015
}

that produces each structural component of the egg. Four parts of the oviduct have different functions in egg production: the infundibulum is the site of fertilization, the magnum is the site of production of egg-white, the isthmus is where the membrane of the shell forms, and the shell gland forming the shell of the egg (Bae et al., 2014). Increasing evidence shows that oviduct injury significantly decreases egg production (Rozenboim et al., 2007; Fan et al., 2014). Therefore, oviduct health is central to egg production. Liebhart et al. (2013) reported that vaccination of pullets to 
attenuate pathological changes in the reproductive tract induced by Histomonas meleagridis could prevent a severe drop in egg production of commercial layers.

At present, high-density cages are the most economical housing system in the commercial layer industry (Xin et al., 2011). However, a number of health problems accompany the economic success of this system, including hepatic lipidosis, renomegaly, osteoporosis, cage layer fatigue, ascites, and inflammation (Burt, 2002; Robins and Phillips, 2011; Buijs et al., 2012). In a previous study, we demonstrated that liver and kidney injury occur in highdensity housed laying hens. Conversely, low-density and free range hens were less affected (data not published). Published reports of the influence of highdensity caging on oviduct health and function are lacking. Sarica et al. (2008) showed that higher density rearing decreased egg production, egg mass, and other performance indicators of hens, and that increasing the space per hen significantly enhanced egg production. Thus, we hypothesized that stocking density or rearing pattern may affect oviduct health and function in hens.

Evidence suggests that stress and disease increase metabolic demand for amino acids, especially sulfur amino acids, to support various aspects of metabolism (Malmezat et al., 1998; 2000). Taurine (Tau), 2-aminoethane sulfonic acid, is the most abundant free amino acid in most animal cells and plays a crucial role in some essential biological processes (Grimble, 2006). Dietary supplementation with taurine and its derivatives has an established role in the prevention and treatment of topical infections, chronic inflammatory, and metabolic diseases (Nagl et al., 2000; Erdem et al., 2008; Ribeiro et al., 2009). In the poultry industry, taurine is used to regulate muscle development, myocardial damage, and other parameters (Ohta et al., 1988; Zielinska et al., 2012). Our laboratory has established that taurine can ameliorate liver and kidney injury in caged laying hens (data not published). There are no reports documenting the effect of taurine on oviduct health and function in hens.

The objective of the present study was to investigate the possibility of enhancing the health of laying hens by reducing housing density and by dietary supplementation with taurine.

\section{Materials and methods}

\subsection{Animals}

Fifteen thousand green-shell laying hens (local cross strain) were reared in the Nanjing Jinshuiwan Ecological Park (Nanjing, China). At 12 weeks of age, they were randomly assigned to three groups: a free range group, a caged group with low-density caged housing (526 $\mathrm{cm}^{2}$ per hen), and a high-density caged group (351 $\mathrm{cm}^{2}$ per hen). Each group was further divided into control $(\mathrm{C})$ and taurine treatment $(\mathrm{T})$ groups (2500 hens per group). Laying hens were sustained under artificial lighting at fixed humidity $((50 \pm 3) \%)$ and temperature $\left((20 \pm 3){ }^{\circ} \mathrm{C}\right)$. The free range group was housed in pastured woods during daylight and confined to indoor pens at night. The nutritive values of the experimental diets provided were set according to commercial recommendations (Table 1).

Table 1 Composition and nutrient content of diets

\begin{tabular}{|c|c|}
\hline Component & Proportion (\%) \\
\hline \multicolumn{2}{|l|}{ Ingredient } \\
\hline Corn & 63.2 \\
\hline Wheat bran & 2.5 \\
\hline Soybean meal & 23.4 \\
\hline Limestone & 6.0 \\
\hline Salt & 0.4 \\
\hline Calcium phosphate & 1.7 \\
\hline DL-Methionine & 0.1 \\
\hline Vitamin-mineral Premix ${ }^{a}$ & 2.7 \\
\hline \multicolumn{2}{|l|}{ Calculated composition } \\
\hline Metabolizable energy & $2600(\mathrm{kcal} / \mathrm{kg})^{*}$ \\
\hline Crude protein & 16.7 \\
\hline Calcium & 3.8 \\
\hline Lysine & 0.9 \\
\hline Available phosphorus & 0.46 \\
\hline \multicolumn{2}{|c|}{$\begin{array}{l}\text { a Vitamin-mineral premix supplied the following (per kg of diet): } \\
\text { vitamin A } 12000 \mathrm{IU} \text {, vitamin } \mathrm{D}_{3} 3500 \mathrm{IU} \text {, vitamin E } 25 \mathrm{IU} \text {, } \\
\text { vitamin } \mathrm{K}_{3} 0.5 \mathrm{mg} \text {, vitamin } \mathrm{B}_{12} 0.014 \mathrm{mg} \text {, thiamine } 1.8 \mathrm{mg} \text {, } \\
\text { riboflavin } 5.2 \mathrm{mg} \text {, D-pantothenic acid } 11 \mathrm{mg} \text {, folic acid } 0.70 \mathrm{mg} \text {, } \\
\text { pyridoxine } 2.5 \mathrm{mg} \text {, niacin } 38 \mathrm{mg} \text {, biotin } 0.15 \mathrm{mg} \text {, microelement } \\
0.1 \mathrm{mg} \text {, betaine } 0.03 \mathrm{mg} \text {, choline chloride } 0.5 \mathrm{mg} \text {, allicin } 0.05 \mathrm{mg} \text {. } \\
{ }^{*} \text { Value is expressed in kcal } / \mathrm{kg}(1 \mathrm{kcal}=4.1868 \mathrm{~kJ})\end{array}$} \\
\hline
\end{tabular}

\subsection{Treatment}

At 21 weeks, the treatment groups were fed with $0.1 \%$ taurine. After $15 \mathrm{~d}, 10$ laying hens selected randomly from each group were dissected, oviduct tissues were aseptically collected, and portions of tissues were immersed in Bouin's stationary liquid or stored at $-80{ }^{\circ} \mathrm{C}$ until analyzed. 


\subsection{Performance measurements}

Every week, 50 chickens in each group were individually weighed and their feed intake and feed to gain ratio were measured. Dead chickens were removed daily and recorded. The survival rate was calculated as the number of surviving hens per cage. Laying rate was calculated as the total egg production of surviving laying hens per day. Daily consumption was calculated as grams of feed taken divided by the number of hens per day, and daily gain was calculated as the increase in weight of hens per day.

\subsection{Preparation of oviduct samples}

Oviduct samples were weighed, then homogenized with sterile physiological saline $(1: 4, \mathrm{w} / \mathrm{v})$ on ice and then centrifuged at $3000 \mathrm{r} / \mathrm{min}$ for $40 \mathrm{~min}$ at $4{ }^{\circ} \mathrm{C}$. Fat was removed and the supernatant was collected and stored at $-20{ }^{\circ} \mathrm{C}$ for subsequent analysis.

\subsection{Histological examination}

Oviduct tissues were immersed in Bouin's stationary liquid for $24 \mathrm{~h}$. Standard dehydration and paraffin-wax embedding procedures were used to produce tissue blocks, which were cut as 5 - $\mu$ m-thick serial sections. After deparaffinization and dehydration, hematoxylin and eosin stained slides were prepared using standard methods.

\subsection{Analysis of inducible nitric oxide synthase (iNOS)}

The activities of iNOS were determined using commercial kits (Nanjing Jiancheng Bioengineering Institute, Nanjing, China) following the manufacturer's protocols. Briefly, the oviduct samples were incubated with $0.6 \mathrm{ml}$ reaction buffer $(5 \mathrm{mmol} / \mathrm{L}$ $\mathrm{MgCl}_{2}, 250 \mathrm{mmol} / \mathrm{L}$ L-valine, $0.2 \mathrm{~mol} / \mathrm{L}$ phosphate buffered saline, $480 \mu \mathrm{mol} / \mathrm{L}$ oxyhemoglobin, and $30 \mathrm{mmol} / \mathrm{L} \mathrm{NADPH})$, combined with an iNOS inhibitor (6 mmol/L ethylene glycol tetraacetic acid (EGTA)). After $15 \mathrm{~min}$ at $37^{\circ} \mathrm{C}$, the reaction was terminated with $10 \mathrm{mmol} / \mathrm{L}$ ethylene diamine tetraacetic acid (EDTA) and $10 \mathrm{mmol} / \mathrm{L}$ HEPES buffer. The colored compound was photometrically measured at a wavelength of $530 \mathrm{~nm}$. iNOS activity was calculated based on the Lambert-Beer Law and expressed as $\mathrm{U} / \mathrm{g}$ protein.

\subsection{Electrophoretic mobility shift assay (EMSA)}

The nuclear factor- $\kappa \mathrm{B}(\mathrm{NF}-\kappa \mathrm{B})$ consensus oligonucleotide (5'-AGTTGAGGGGACTTTCCCAGGC-3') was used as a DNA probe and labeled with a biotin 3 '-end. Following laboratory's protocols, NF- $\kappa \mathrm{B}$ probe was incubated for $30 \mathrm{~min}$ with $15 \mu \mathrm{g}$ of nuclear extract in $20 \mu \mathrm{l}$ of binding buffer. The samples were then loaded onto a $5 \%$ non-denaturing polyacrylamide gel for $2 \mathrm{~h}$ with $0.5 \times$ Tris-borate/EDTA (TBE) on ice at $80 \mathrm{~V}$. The samples were transferred to a positively charged nylon membrane (Millipore, Bedford, MA, USA), and cross-linked for $12 \mathrm{~min}$ using a UV-light. Then, following the manufacturer's protocols, binding DNA was detected by enhanced chemiluminescence (Pierce, USA) and quantified by

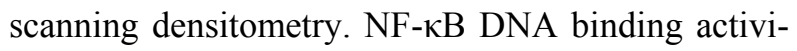
ties were expressed as relative integrated intensity.

\subsection{RNA extraction and reverse transcription-} polymerase chain reaction (RT-PCR)

\subsubsection{RNA extraction}

Following the laboratory's protocols, total RNA was extracted from oviduct tissue using TRIzol reagent (TaKaRa, Tokyo, Japan). The concentration was measured using a BioPhotometer (Eppendorf, Hamburg, Germany).

\subsubsection{Real-time quantitative RT-PCR}

According to the laboratory's protocols, the complementary DNA (cDNA) samples were mixed with $25 \mu \mathrm{SYBR}^{\circledR}$ Green PCR Master Mix (TaKaRa, Tokyo, Japan) and 10 pmol of each forward and reverse primer for tumor necrosis factor- $\alpha$ (TNF- $\alpha)$, interferon- $\gamma$ (IFN- $\gamma$ ), interleukin 4 (IL-4), and IL-10 (Table 2). All primer sequences were synthesized by the Invitrogen Biological Company (Shanghai, China). Mixtures were incubated in an ABI Prism 7300 Sequence Detection System (Applied Biosystems, USA) programmed to conduct one cycle at $95{ }^{\circ} \mathrm{C}$ for $10 \mathrm{~min}$ and 43 cycles at $95{ }^{\circ} \mathrm{C}$ for $15 \mathrm{~s}$ and $62{ }^{\circ} \mathrm{C}$ for $1 \mathrm{~min}$. Results (fold changes) were expressed as $2^{-\Delta \Delta C_{\mathrm{T}}}$ with $\Delta \Delta C_{\mathrm{T}}=\left(C_{\mathrm{T}, i, j}-C_{\mathrm{T}, \beta \text {-actin }, j}\right)-\left(C_{\mathrm{T}, i, 1}-C_{\mathrm{T}, \beta \text {-actin, } 1}\right)$, where $C_{\mathrm{T}, i, j}$ and $C_{\mathrm{T}, \beta \text {-actin, } j}$ are the $C_{\mathrm{T}}$ for gene $i$ and for $\beta$-actin, respectively, in a sample (named $j$ ), and where $C_{\mathrm{T}, i, 1}$ and $C_{\mathrm{T}, \beta \text {-actin, } 1}$ are the $C_{\mathrm{T}}$ in sample 1, expressed as the standard. In this study, the free 
Table 2 Primer sequences of targeted genes and $\beta$-actin

\begin{tabular}{clll}
\hline Gene & Accession number & Primer sequence $\left(5^{\prime} \rightarrow 3^{\prime}\right)$ & Orientation \\
\hline$\beta$-actin & L08165 & TGCGTGACATCAAGGAGAAG & Forward \\
& & TGCCAGGGTACATTGTGGTA & Reverse \\
$T N F-\alpha$ & JN942589.1 & GATGGGAAGGGAATGA & Forward \\
& & ACAGGAAGGGCAACTC & Reverse \\
$I F N-\gamma$ & NM205149.1 & GAGCCATCACCAAGAA & Forward \\
& & ATAGGTCCACCGTCAG & Reverse \\
$I L-4$ & GU119892.1 & CAGCACTGCCACAAGA & Forward \\
& & AGTTGGTGGAAGAAGGTA & Reverse \\
$I L-10$ & NM001004414.2 & GCTGAGGGTGAAGTTTG & Forward \\
& & GGTGAAGAAGCGGTGA & Reverse \\
\hline
\end{tabular}

Table 3 Survival rate, laying rate, daily consumption, and daily gain of laying hens raised under different conditions

\begin{tabular}{ccccc}
\hline Performance & $\begin{array}{c}\text { Survival rate } \\
(\%)\end{array}$ & $\begin{array}{c}\text { Average laying rate } \\
(\%)\end{array}$ & $\begin{array}{c}\text { Average daily consumption } \\
(\mathrm{g} / \text { per hen })\end{array}$ & $\begin{array}{c}\text { Average daily gain } \\
(\mathrm{g} / \text { per hen })\end{array}$ \\
\hline Free range & & & & \\
C & $91.67 \pm 2.80$ & $39.10 \pm 2.83^{\mathrm{a}}$ & $99.30 \pm 3.17^{\mathrm{a}}$ & $2.86 \pm 0.14$ \\
T & $94.05 \pm 2.04^{* \mathrm{~A}}$ & $44.21 \pm 2.57^{* \mathrm{~A}}$ & $96.77 \pm 2.13^{\mathrm{A}}$ & $2.95 \pm 0.12$ \\
Low density & & & & \\
C & $95.37 \pm 1.96^{\mathrm{a}}$ & $53.49 \pm 1.78^{\mathrm{b}}$ & $87.73 \pm 1.65^{\mathrm{b}}$ & $3.16 \pm 0.09$ \\
T & $98.53 \pm 1.28^{* \mathrm{~B}}$ & $57.62 \pm 1.10^{* \mathrm{~B}}$ & $85.11 \pm 2.89^{\mathrm{B}}$ & $3.17 \pm 0.12$ \\
High density & & & & \\
C & $92.13 \pm 3.07$ & $51.02 \pm 3.26^{\mathrm{ab}}$ & $85.91 \pm 2.39^{\mathrm{b}}$ & $3.27 \pm 0.15$ \\
T & $96.76 \pm 1.61^{* \mathrm{AB}}$ & $54.30 \pm 1.89^{\mathrm{AB}}$ & $84.45 \pm 2.25^{\mathrm{B}}$ & $3.32 \pm 0.08$ \\
\hline
\end{tabular}

Data are presented as the mean $\pm \operatorname{SEM}(n=10)$. C: control; T: taurine treatment. ${ }^{*}$ Significant difference between control and treatment groups in the same rearing pattern $(P<0.05)$. Superscripts not sharing a common letter in a column differ significantly (small letters for control groups and capital letters for treatment groups; $P<0.05$ )

range control group was determined as standard, thus leading to a relative expression of $1=20$ in this group (Miao et al., 2013).

\subsection{Analyses of total anti-oxidation capability (T-AOC), superoxide dismutase (SOD), and malondialdehyde (MDA) levels}

T-AOC, SOD, and MDA levels in oviduct homogenate were determined using commercial kits purchased from the Nanjing Jiancheng Bioengineering Institute (Nanjing, China). According to the manufacturer's protocols, briefly, T-AOC was measured as absorbance of the reaction mixture at $520 \mathrm{~nm}$ per $\mathrm{mg}$ of protein at $37^{\circ} \mathrm{C}$. SOD was measured at $550 \mathrm{~nm}$ and expressed as $\mathrm{U} / \mathrm{mg}$ of protein (oviduct tissue). MDA was measured at $532 \mathrm{~nm}$ and expressed as nmol/mg of protein (oviduct tissue).

\subsection{Statistical analyses}

All statistical procedures, mean, and standard errors of mean (SEM) were computed using the statistical software SPSS 16.0 (SPSS Inc., Chicago,
IL, USA). Data are expressed as mean \pm SEM. Differences were evaluated by one-way analysis of variance (ANOVA).

\section{Results}

\subsection{Laying hen performance}

The survival rate and average laying rate were higher in caged hens (Table 3). Compared with the free range group, there was a significant increase in the lower-density group $(P<0.05)$. In the caged groups, the survival rate in the low-density group was higher than that in the high-density group $(P<0.05)$. Dietary supplementation with taurine increased the survival rate in all three rearing systems and the average laying rate was higher in the free range and low-density groups. The average daily feed consumption was lower in the caged groups compared with the free range groups $(P<0.05)$. No significant changes were present in average daily gain among the different groups $(P>0.05)$. 


\subsection{Histological examination}

In the high-density caged $\mathrm{C}$ groups, infiltration of erythrocytes and neutrophils into the oviduct was greater than in the other groups. In the low-density caged $\mathrm{C}$ group, there were small numbers of neutrophils in the oviducts. In the free caged $\mathrm{C}$ group, inflammatory cells were rare (Figs. 1a-1c).

In the $\mathrm{T}$ groups, oviduct epithelial lining cells were regularly arranged and were shedding villi, and small numbers of red blood cells (RBC) and neutrophils were present in the mucosa and submucosa (Figs. 1d-1f). The T groups had significantly fewer of these cells than the $\mathrm{C}$ groups.
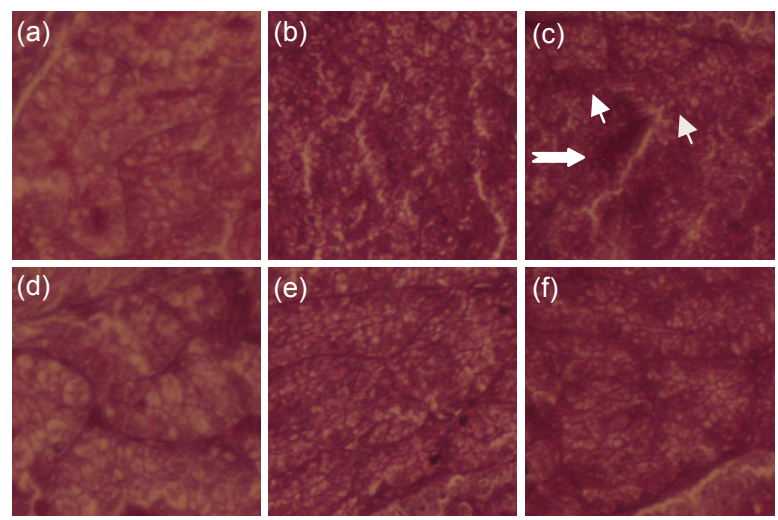

Fig. 1 Histology of the oviduct in laying hens Oviduct sections are stained with hematoxylin and eosin (H\&E). (a) Free range control group; (b) Low-density control group; (c) High-density control group; (d) Free range taurine treatment group; (e) Low-density taurine treatment group; (f) High-density taurine treatment group. Thin arrow: neutrophils; Thick arrow: erythrocyte. Original magnification: $200 \times$

\subsection{Effect of taurine and different housing modes on NF-кB DNA binding activity}

In the $\mathrm{C}$ groups, NF- $\kappa \mathrm{B}$ DNA binding activity was higher in the high-density group than in the free range and low-density groups $(P<0.05$ for both) (Fig. 2a). Taurine had significantly less binding activity in the high-density group $(P<0.05)$ (Fig. 2b).

\subsection{Changes in iNOS}

Oviduct iNOS activities were higher in the caged hens than in the free range groups. Taurine supplementation did not cause a significantly decrease in iNOS activity among rearing systems (Fig. 3). (a)

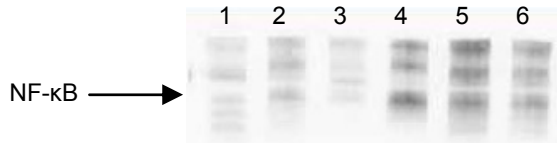
$\mathrm{N}$

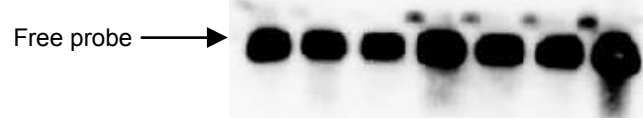

(b)

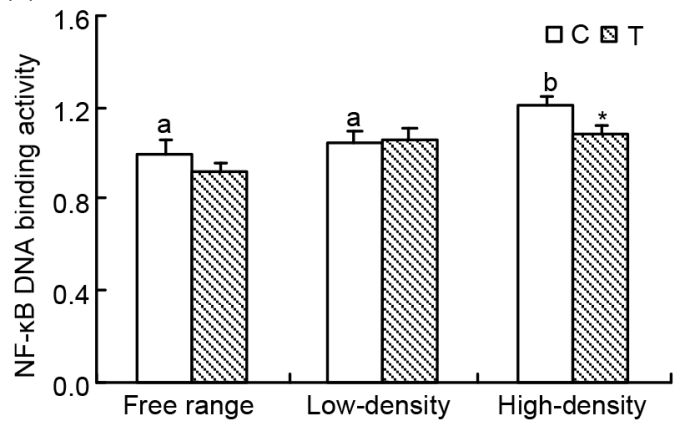

Fig. 2 Effect of taurine on NF-кB DNA binding activity by EMSA analysis in oviduct tissue from laying hens

(a) Lanes 1 and 2 are control and treatment groups in a free range environment; Lanes 3 and 4 are control and treatment groups in a low-density caged environment; Lanes 5 and 6 are control and treatment groups in a high-density caged environment; Lane $\mathrm{N}$ is a negative control. (b) Results of statistical analysis for NF- $\kappa B$ DNA binding activities. Data are presented as the mean $\pm \operatorname{SEM}(n=10) .{ }^{*}$ Significant difference between control and treatment groups in the same rearing pattern $(P<0.05)$. The means not sharing a common letter are significantly different for control groups $(P<0.05)$

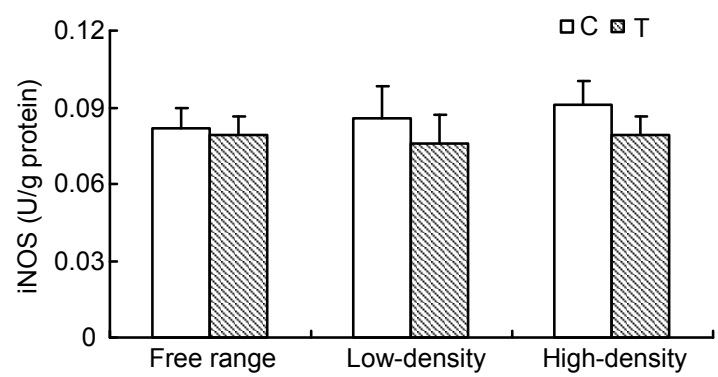

Fig. 3 Changes in oviduct iNOS of laying hens housed in different conditions

Data are presented as mean $\pm \operatorname{SEM}(n=10)$ 


\subsection{Real-time quantitative RT-PCR analysis of gene expression}

Compared with the free range group, TNF- $\alpha$ mRNA expression in the high-density and lowdensity groups increased significantly in the $\mathrm{C}$ and $\mathrm{T}$ groups $(P<0.05$ for both). Dietary taurine remarkably reduced the expression of TNF- $\alpha$ mRNA in the free range and low-density groups $(P<0.05$ for both) (Fig. 4a). In the high-density $\mathrm{C}$ group, IFN- $\gamma$ mRNA expression was higher than in the free range group $(P<0.05)$. Supplementation with taurine significantly decreased IFN- $\gamma$ mRNA expression in the lowdensity group $(P<0.05)$ (Fig. 4b). IL-4 mRNA expression was significantly higher in caged hens than in free range hens $(P<0.05)$ (Fig. 4c). IL-10 mRNA expression was higher in the high-density $\mathrm{C}$ group than in the free range and low-density $\mathrm{C}$ groups $(P<0.05$ for both). Supplementation with taurine decreased IL-10 mRNA expression significantly in the high-density group $(P<0.05)$ (Fig. $4 d)$.

\subsection{Activities of SOD and levels of T-AOC and MDA in the oviduct}

There were no significant differences in MDA and T-AOC levels among the different groups
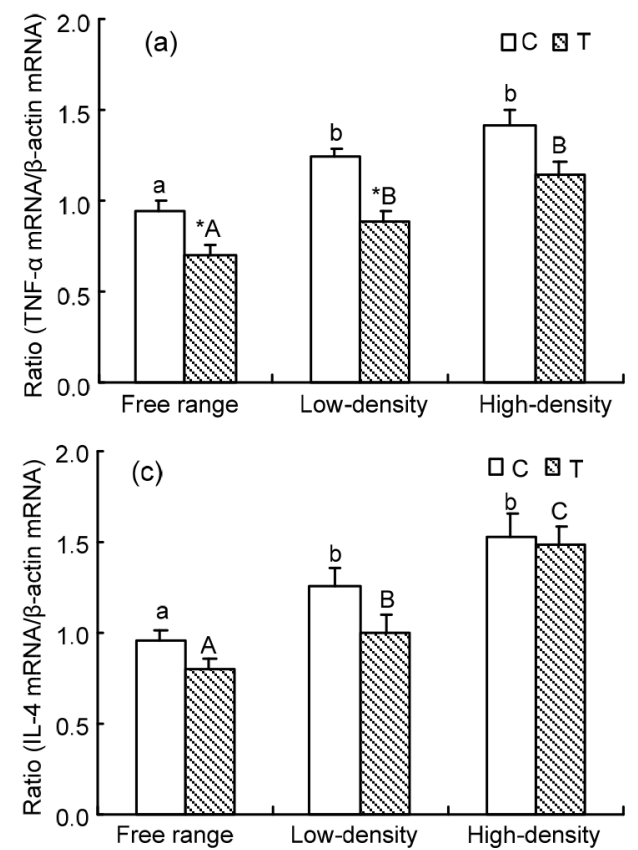

(Figs. 5a and 5c). Supplementation with taurine increased SOD activity in the free range hens $(P<0.05$; Fig. 5b).

\section{Discussion}

We quantified performance traits including survival rate, laying rate, daily feed consumption, and daily weight gain. These parameters are important to the egg industry. The higher survival and average laying rates in caged hens further establish that caging is financially advantageous to the commercial layer industry. However, housing density is important. As demonstrated in our study, the survival rate and average laying rate were significantly higher in the low-density group than in the free range group. Dietary taurine supplementation improved egg production as previously reported (Wang et al., 2010). Thus, both taurine supplementation and reduced stocking density can be used to improve the production performance of laying hens.

Oviduct health is closely related to production performance. We hypothesized that dietary taurine supplementation and reduced housing density are linked to increased production via improved oviduct
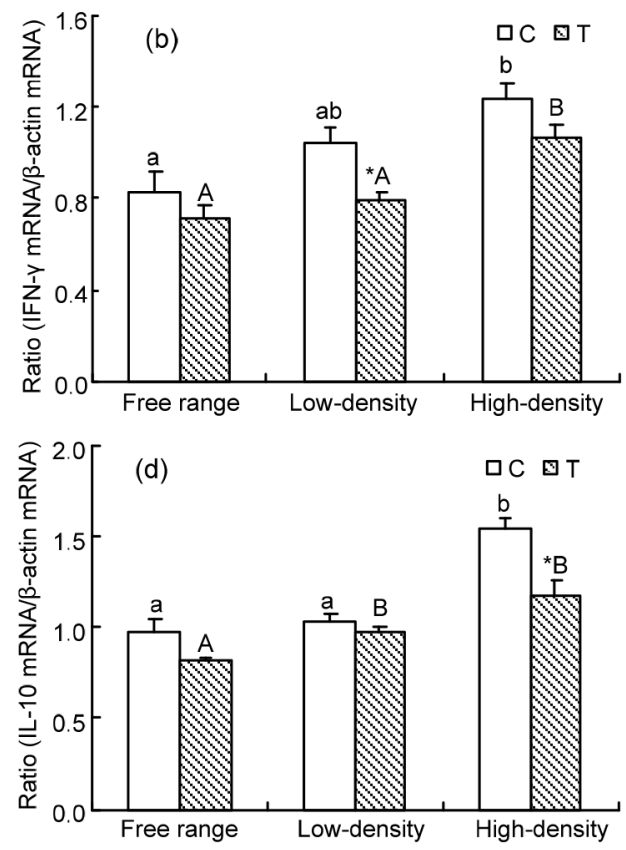

Fig. 4 Changes in TNF- $\alpha$ (a), IFN- $\gamma$ (b), IL-4 (c), and IL-10 (d) gene expression in oviducts of laying hens housed in different conditions

The expression levels of each gene were determined by real-time RT-PCR, and the expressed RNA levels were normalized to $\beta$-actin as a ratio of the gene of interest/ $\beta$-actin mRNA levels. Data are presented as mean $\pm \operatorname{SEM}(n=10) .{ }^{*}$ Significant difference between control and treatment groups in the same rearing pattern $(P<0.05)$. The means not sharing a common letter are significantly different (small letters for control groups and capital letters for treatment groups; $P<0.05)$ 

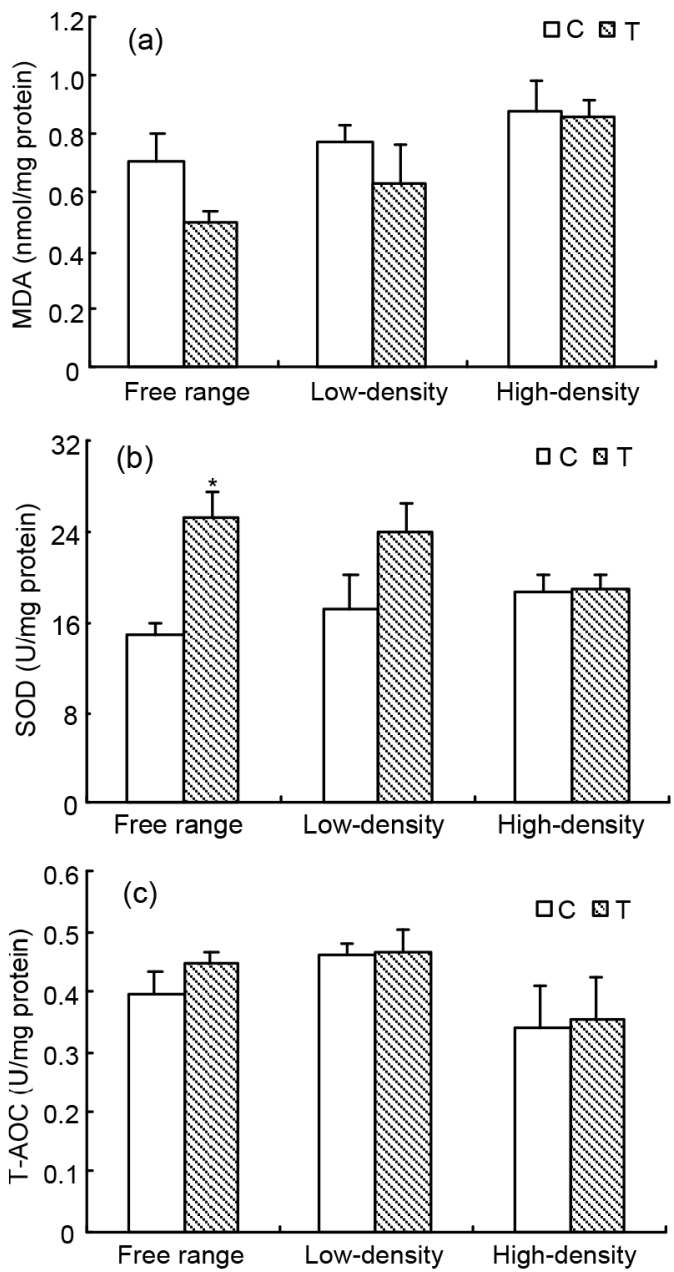

Fig. 5 Changes in MDA (a) and T-AOC (c) levels and SOD activity (b) in the oviduct of laying hens housed in different conditions

Data are presented as the mean $\pm \operatorname{SEM}(n=10) .{ }^{*}$ Significant difference between control and treatment groups in the same rearing pattern $(P<0.05)$

function. In the current study, we investigated histological changes in the different groups. More erythrocytes and neutrophils infiltrated the oviducts in the high-density housing group than in the free range and low-density housing groups, respectively. Additionally, inflammatory cell infiltration was more severe in the $\mathrm{C}$ groups than in the $\mathrm{T}$ groups. Numerous previous studies have reported that inflammatory cell infiltration is the first step in metabolic and inflammatory diseases (Grisham et al., 1986; Miao et al., 2012). Therefore, the oviducts of laying hens reared in a high-density environment could be protected from injury by taurine supplementation or by lowering the housing density.
$\mathrm{NF}-\kappa \mathrm{B}$ is a transcription factor that is constitutively expressed in almost all tissues and has a crucial role as a transcriptional regulator responding to stress and infection. Normally, the signaling pathway mediated by NF- $\mathrm{KB}$ has been considered both antiapoptotic and pro-inflammatory and is implicated in the pathogenesis of many diseases, including inflammatory disorders and tumorigenesis (Robinson and Mann, 2010; Baker et al., 2011; He and Karin, 2011). In metabolic diseases, the activation of NF- $\mathrm{KB}$ plays a central role in tissue damage (Yin et al., 2012). In the current study, NF- $\mathrm{KB}$ DNA binding activity was significantly lower in the free range and lowdensity groups than in the high-density group. Taurine supplementation decreased NF- $\kappa$ B DNA binding activity in the high-density groups. Thus, we conclude that reducing the inflammatory reaction is one of the mechanisms by which dietary taurine and lower density reduce oviduct injury. This conclusion is supported by measurement of TNF- $\alpha$ mRNA expression and iNOS activity, which are downstream effector molecules of the NF-kB pathway. Our data show that TNF- $\alpha$ mRNA expression was markedly reduced by taurine supplementation and lower housing density.

Immune cell infiltration is another feature of the inflammatory reaction and the status of the immune cells in tissues is a reliable measure for assessing animal health. $\mathrm{CD}^{+} \mathrm{T}$ helper (Th) lymphocytes are integral to an effective immune response. $\mathrm{CD}^{+} \mathrm{T}$ cells have been classified into two major types, Th1 and Th2 (Crews et al., 2006; Miao et al., 2009). INF- $\gamma$ is one of the primary pro-inflammatory Th1 cytokines. The current data indicate that INF- $\gamma$ mRNA expression in the oviduct was increased in the high-density group. Laying hens in the low-density and free range groups had lower levels of Th1 cytokines than those in the high-density group, and taurine supplementation decreased INF- $\gamma$ mRNA expression in the oviduct. This demonstrates that low-density housing and taurine supplementation may suppress the expression of proinflammatory Th1 cytokines.

IL-4 and IL-10 are the main anti-inflammatory cytokines, well known for their pro-Th2 effects during $\mathrm{T}$ cell differentiation (Marçais et al., 2013). The present study demonstrates that the expressions of IL-4 and IL-10 mRNA in the oviduct were increased significantly in the high-density group. Dietary 
taurine supplementation and lower housing density can decrease IL-4 and IL-10 levels (in the high-density group, IL-10 mRNA expression decreased significantly with taurine supplementation). The Th1/Th2 ratio plays a key role in the process of disease (Hossain et al., 2001; Schulze-Koops and Kalden, 2001). Our data indicate that a reduced housing density and dietary supplementation with taurine might better balance the $\mathrm{Th} 1 / \mathrm{Th} 2$ ratio and protect the oviduct from inflammation.

Oxidative stress is caused by increased oxidants or decreased antioxidant defense that damages cellular function and takes part in the pathophysiological changes of many diseases (Kaneto et al., 1999; Beshay and Carrier, 2004). T-AOC levels reflect the activity of scavenging free radicals (Lewis et al., 1995). SOD can catalyze $\mathrm{O}_{2}{ }^{-}$disproportionately into $\mathrm{H}_{2} \mathrm{O}_{2}$ and $\mathrm{O}_{2}$ (Lewis et al., 1995; Tian et al., 2011). MDA is a product of lipid peroxidation, which is often used as a bio-marker of tissue oxidative stress and cell damage (Parikh et al., 2003; Wu et al., 2012). There were no significant differences in MDA and T-AOC levels among the different groups in this study. Dietary taurine supplementation increased SOD activities in the free range hens. These results are consistent with several other studies showing that taurine has an anti-oxidant role (Lakshmi Devi and Anuradha, 2010; Oliveira et al., 2010).

In summary, we demonstrated that taurine has important protective effects against oviduct damage. Reducing housing density also results in less oxidative stress, less inflammatory cell infiltration, and lower levels of inflammatory mediators in the oviduct. Therefore, both dietary taurine and reduced housing density can be used to ameliorate oviduct injury, enhance health, and promote the production performance of laying hens.

\section{Acknowledgements}

The authors wish to express their thanks to Dr. Howard GELBERG (Oregon State University, USA) for manuscript editing.

\section{Compliance with ethics guidelines}

Bin DAI, Yuan-shu ZHANG, Zi-li MA, Liu-hai ZHENG, Shuang-jie LI, Xin-hong DOU, Jian-sen GONG, and Jin-feng MIAO declare that they have no conflict of interest.

All institutional and national guidelines for the care and use of laboratory animals were followed.

\section{References}

Bae, S.M., Lim, W., Jeong, W., et al., 2014. Hormonal regulation of beta-catenin during development of the avian oviduct and its expression in epithelial cell-derived ovarian carcinogenesis. Mol. Cell Endocrinol., 382(1): 46-54. [doi:10.1016/j.mce.2013.09.010]

Baker, R.G., Hayden, M.S., Ghosh, S., 2011. NF-кB, inflammation, and metabolic disease. Cell Metab., 13(1): 11-22. [doi:10.1016/j.cmet.2010.12.008]

Beshay, E., Carrier, S., 2004. Oxidative stress plays a role in diabetes-induced bladder dysfunction in a rat model. Urology, 64(5):1062-1067. [doi:10.1016/j.urology.2004. 06.021]

Buijs, S., van Poucke, E., van Dongen, S., et al., 2012. The influence of stocking density on broiler chicken bone quality and fluctuating asymmetry. Poult. Sci., 91(8): 1759-1767. [doi:10.3382/ps.2011-01859]

Burt, D., 2002. Applications of biotechnology in the poultry industry. Worlds Poult. Sci. J., 58(1):5-13. [doi:10.1079/ WPS20020002]

Crews, F.T., Bechara, R., Brown, L.A., et al., 2006. Cytokines and alcohol. Alcohol. Clin. Exp. Res., 30(4):720-730. [doi:10.1111/j.1530-0277.2006.00084.x]

Erdem, A., Sevgili, A.M., Akbiyik, F., et al., 2008. The effect of taurine on mesenteric blood flow and organ injury in sepsis. Amino Acids, 35(2):403-410. [doi:10.1007/s00726007-0622-0]

Fan, S., Zheng, J., Duan, Z., et al., 2014. The influences of SE infection on layers' production performance, egg quality and blood biochemical indicators. J. Anim. Sci. Biotechnol., 5(1):4-9. [doi:10.1186/2049-1891-5-4]

Grimble, R.F., 2006. The effects of sulfur amino acid intake on immune function in humans. J. Nutr., 136(6):1660S$1665 \mathrm{~S}$.

Grisham, M.B., Hernandez, L.A., Granger, D.N., 1986. Xanthine oxidase and neutrophil infiltration in intestinal ischemia. Am. J. Physiol., 251(4 Pt 1):G567-G574.

He, G., Karin, M., 2011. NF-кB and STAT3-key players in liver inflammation and cancer. Cell Res., 21(1):159-168. [doi:10.1038/cr.2010.183]

Hossain, A., Zheng, C.L., Kukita, A., et al., 2001. Balance of Th1/Th2 cytokines associated with the preventive effect of incomplete Freund's adjuvant on the development of adjuvant arthritis in LEW rats. J. Autoimmun., 17(4): 289-295. [doi:10.1006/jaut.2001.0552]

Kaneto, H., Kajimoto, Y., Miyagawa, J., et al., 1999. Beneficial effects of antioxidants in diabetes: possible protection of pancreatic beta-cells against glucose toxicity. Diabetes, 48(12):2398-2406. [doi:10.2337/diabetes.48.12. 2398]

Lakshmi Devi, S., Anuradha, C.V., 2010. Mitochondrial damage, cytotoxicity and apoptosis in iron-potentiated alcoholic liver fibrosis: amelioration by taurine. Amino Acids, 38(3):869-879. [doi:10.1007/s00726-009-0293-0]

Lewis, S.E., Boyle, P.M., McKinney, K.A., et al., 1995. Total antioxidant capacity of seminal plasma is different in fertile and infertile men. Fertil. Steril., 64(4):868-870.

Liebhart, D., Sulejmanovic, T., Grafl, B., et al., 2013. Vaccination against histomonosis prevents a drop in egg 
production in layers following challenge. Avian Pathol., 42(1):79-84. [doi:10.1080/03079457.2012.760841]

Malmezat, T., Breuillé, D., Pouyet, C., et al., 1998. Metabolism of cysteine is modified during the acute phase of sepsis in rats. J. Nutrl., 28(1):97-105.

Malmezat, T., Breuillé, D., Pouyet, C., et al., 2000. Methionine transsulfuration is increased during sepsis in rats. Am. J. Physiol. Endocrinol. Metab., 279(6):E1391-E1397.

Marçais, A., Viel, S., Grau, M., et al., 2013. Regulation of mouse NK cell development and function by cytokines. Front. Immunol., 4:450. [doi:10.3389/fimmu.2013.00450]

Miao, J.F., Zhang, Y.S., Huang, G.Q., et al., 2009. Polysaccharide nucleic acid of Bacillus Calmette Guerin modulates Th1/Th2 cytokine gene expression in lipopolysaccharide-induced mastitis in rats. Agric. Sci. Chin., 8(8):1010-1018. [doi:10.1016/S1671-2927(08) 60308-9]

Miao, J.F., Zhang, J.Q., Zheng, L.H., et al., 2012. Taurine attenuates Streptococcus uberis-induced mastitis in rats by increasing $\mathrm{T}$ regulatory cells. Amino Acids, 42(6): 2417-2428. [doi:10.1007/s00726-011-1047-3]

Miao, J.F., Zhang, J.Q., Ma, Z.L., et al., 2013. The role of NADPH oxidase in taurine attenuation of Streptococcus uberis-induced mastitis in rats. Int. Immunopharmacol., 16(4):429-435. [doi:10.1016/j.intimp.2013.05.007]

Nagl, M., Hess, M.W., Pfaller, K., 2000. Bactericidal activity of micromolar $\mathrm{N}$-chlorotaurine: evidence for its antimicrobial function in the human defense system. Antimicrob. Agents Chemother., 44(9):2507-2513. [doi:10.1128/AAC.44.9.2507-2513.2000]

Ohta, H., Azuma, J., Awata, N., et al., 1988. Mechanism of the protective action of taurine against isoprenaline induced myocardial damage. Cardiovasc. Res., 22(6):407-413. [doi:10.1093/cvr/22.6.407]

Oliveira, M.W., Minotto, J.B., de Oliveira, M.R., et al., 2010. Scavenging and antioxidant potential of physiological taurine concentrations against different reactive oxygen/ nitrogen species. Pharmacol. Rep., 62(1):185-193. [doi: 10.1016/S1734-1140(10)70256-5]

Parikh, V., Khan, M.M., Mahadik, S.P., 2003. Differential effects of antipsychotics on expression of antioxidant enzymes and membrane lipid peroxidation in rat brain. $J$. Psychiatr. Res., 37(1):43-51. [doi:10.1016/S0022-3956 (02)00048-1]

Ribeiro, R.A., Bonfleur, M.L., Amaral, A.G., et al., 2009. Taurine supplementation enhances nutrient-induced insulin secretion in pancreatic mice islets. Diabetes Metab. Res. Rev., 25(4):370-379. [doi:10.1002/dmrr.959]

Robins, A., Phillips, C., 2011. International approaches to the welfare of meat chickens. World's Poult. Sci. J., 67(2): 351-369. [doi:10.1017/S0043933911000341]

Robinson, S.M., Mann, D.A., 2010. Role of nuclear factor $\kappa B$ in liver health and disease. Clin. Sci., 118(12):691-705. [doi:10.1042/CS20090549]

Rozenboim, I., Tako, E., Gal-Garber, O., 2007. The effect of heat stress on ovarian function of laying hens. Poult. Sci., 86(8):1760-1765. [doi:10.1093/ps/86.8.1760]

Sarica, M., Boga, S., Yamak, U.S., 2008. The effects of space allowance on egg yield, egg quality and plumage condition of laying hens in battery cages. Czech. J. Anim. Sci., 53:346-353.

Schulze-Koops, H., Kalden, J.R., 2001. The balance of Th1/Th2 cytokines in rheumatoid arthritis. Best Pract. Res. Clin. Rheumatol., 15(5):677-691. [doi:10.1053/berh. 2001.0187]

Tian, Y., Zou, B., Yang, L., et al., 2011. High molecular weight persimmon tannin ameliorates cognition deficits and attenuates oxidative damage in senescent mice induced by D-galactose. Food Chem. Toxicol., 49(8): 1728-1736. [doi:10.1016/j.fct.2011.04.018]

Wang, F.R., Dong, X.F., Zhang, X.M., et al., 2010. Effects of dietary taurine on egg production, egg quality and cholesterol levels in Japanese quail. J. Sci. Food Agric., 90(15):2660-2663. [doi:10.1002/jsfa.4136]

Wu, X.Q., Kong, X., Zhou, Y., et al., 2012. Sesamin exerts renoprotective effects by enhancing NO bioactivity in renovascular hypertensive rats fed with high-fat-sucrose diet. Eur. J. Pharmacol., 683(1-3):231-237. [doi:10. 1016/j.ejphar.2012.01.029]

Xin, H., Gates, R.S., Green, A.R., et al., 2011. Environmental impacts and sustainability of egg production systems. Poult. Sci., 90(1):263-277. [doi:10.3382/ps.2010-00877]

Yin, H., Miao, J., Ma, C., et al., 2012. $\beta$-Casomorphin-7 cause decreasing in oxidative stress and inhibiting NF- $\mathrm{kB}-$ iNOS-NO signal pathway in pancreas of diabetes rats. $J$. Food Sci., 77(2):C278-C282. [doi:10.1111/j.1750-3841. 2011.02577.x]

Zielinska, M., Sawosz, E., Grodzik, M., et al., 2012. Effect of taurine and gold nanoparticles on the morphological and molecular characteristics of muscle development during chicken embryogenesis. Arch. Anim. Nutr., 66(1):1-13. [doi:10.1080/1745039X.2011.644918]

\section{中文概要}

题 目: 日粮中添加牛磺酸对不同饲养方式蛋鸡输卵管功 能的影响

目 的: 本研究旨在调查饲喂牛磺酸和降低饲养密度对蛋 鸡输卵管功能的影响。

创新点: 着眼于动物健康的动物福利, 探讨在现代社会高 密度饲养的笼养鸡伴随的许多健康问题。

方 法: 在本研究中, 绿壳蛋鸡被随机分为散养组、低密 度组和高密度组, 每组又被分为对照组和饲喂牛 磺酸实验组。每个组别的蛋鸡日常饮食是一样 的, 除了实验组中添加 $0.1 \%$ 的牛磺酸。 15 天后, 无菌采集输卵管组织, 并分析了组织病理学学上 的变化、炎症介质水平、氧化和抗氧化水平等指 标的变化。

结 论: 这些数据表明牛磺酸可以保护输卵管组织, 降低 炎症介质水平、氧化水平以及增强抗氧化水平 等。另外, 散养和低密度饲养同样能降低氧化应 激和输卵管炎症因子水平等。

关键词: 饲养模式; 牛磺酸; 蛋鸡; 炎症; 输卵管损伤 